\title{
MOTIVATION AND LEARNING STRATEGIES IN UNIVERSITY COURSES IN ITALIAN LANGUAGE
}

\author{
Prof. Neala Ambrosi-Randić, PhD. \\ Juraj Dobrila University of Pula (Croatia) \\ e-mail: neala.ambrosi-randic@pu.t-com.hr
}

Helena Ružić, BA

\begin{abstract}
Summary
The present work explores relationships among motivation, the use of learning strategies and anxiety. In this research 93 university students took part; 84 females and 9 males, 19 to 26 years old. Obtained results indicate existence of positive and significant correlations between motivation and the use of learning strategies. More motivated students organise their personal activities better, they are more active during lectures and they elaborate materials better compared to the less motivated students. Anxiety influences the motivation process, so that more anxious students are more motivated than the less anxious ones. The data confirm that moderate levels of anxiety can influence the learning process in a positive way, enhancing positive effects on activity and outcomes.
\end{abstract}

Key words: motivation, learning strategies, anxiety

\section{Introduction}

The elements that define a learning process are: a) exposure to the object of learning; b) the opportunity to use what has been learnt; c) motivation to respond to the previous two conditions (Bindra, Stewart, 1969). Motivation is, therefore, one of the preliminary conditions of every learning and it ends up to be taken for granted, a factor pervasive but secure (Mariani, 2007). In general terms motivation can be defined as an organised pattern of three psychological functions that serve to lead, activate and regulate activity directed to a goal achievement: personal goals, emotional processes and personal convictions about the own capacity of acting towards accomplishing a determined goal (Ford, 1992, in: Boscolo, 2002).

Without any doubt it can be said that motivation varies: it is high if an activity is interesting, and it becomes reduced if an imposed activity is far from interests or personal capacities. Unfortunately personal interests do not coincide always with university or working activities. However, students that are considered good, or workers 
estimated to be great, have one thing in common. Whenever they face an activity they dislike or find unattractive, they seek to think how it could be useful (now or in the future), and this explanation creates the right level of motivation that encourages them to finish the work and to be successful. Obviously, motivation is not the only ingredient for having good results, but it makes contribution together with invested effort, methodical work as well as knowing strategies that facilitate learning (Cornoldi, De Beni and the Group MT, 1993).

Besides variability, motivation has another important feature: its origin. It means that motivation can have origin within the person or outside the person. Therefore we can talk about intrinsic and extrinsic motivation. Intrinsic motivation has its origin within the person and is very efficient because it results from a genuine interest. Behaviour motivated intrinsically finds gratification in itself, and it is visible especially in conditions that enable the person to feel autonomous, and to regulate his/her own learning. This brings to involving more efforts in order to accomplish more gratifying result. Generally, this type of motivation that stems within a person is considered to be one of the most important and more efficient.

Extrinsic motivation, on the contrary, pushes a person to employ the efforts knowing that at the end he/she will get a reward. It refers to activities that a person employs in order to obtain advantages, avoid unpleasant consequences, have acknowledgement or adapt to models of behaviour imposed by the society. Extrinsic motivation tends to achieve external goals rather than the activity itself. This type of motivation can be little efficient if the award is less attractive and if there are no other good reasons to put effort for.

In reality motivation always oscillates on an intrinsic-extrinsic continuum, because people are motivated at the same time by multiple factors, very different and sometimes even conflicting. For this reason it is good to change the point of view and to consider this important aspect of learning as a dynamic construct and as a true and genuine multidimensional competence to construct and nurture. Persons (including, of course, teachers) contribute in creating a larger system in which particular systems interact. Mariani says (2008) this is a system that should be able to respond to deep personal needs, but at the same time it is a system that continuously interferes with other systems, such as university with its complexity and family, spreading to more general systems of the community, market and society. So, motivation is also a multidimensional construct: not only from the psychological point of view - as focused to individual personality dynamics, but also from the socio-cultural point of view - as a result of interactions of a person with the surroundings that conditions satisfaction of deep personal needs (Mariani, 2007). If we accept this perspective of motivation as a system, the theory of complex systems can be found useful. According to the theory of complex systems or the theory of chaos (Mariani, 2008), motivation is a system to such an extent dynamic and unpredictable, as well as very sensitive to every little variation of the context, enough to be defined as chaos.

According to this, learning to self-regulate oneself and becoming more mature, is a personal and delicate process that needs to be encouraged and facilitated. This is a characteristic of the learning process that tackles directly one of motivational 
dimensions; it is the stimulation towards strategic self-regulation, by using learning strategies. The learning strategies are steps, operations and behaviour implemented by the learner in order to facilitate, optimise and accelerate the personal processes of learning (Mariani, 2006). The choice and the usage of strategies, as well as their efficacy, depend on various factors: individual differences, characteristics of the tasks and strategies used by the teacher. In this context impact between the strategies used by a student and those used by a teacher is also important. A classification based on learning strategies distinguishes: a) strategies of selection, comprehension and organisation of knowledge; b) strategies of motivational self-regulation; c) strategies of assistance: surroundings of learning and looking for help. The role of strategies is, basically, to promote task solving, especially when problems occur. The principal role of the strategic behaviour is to optimise student's resources and to achieve the wanted goal in not easy situations.

In the more prominent situations, the strategies can be transformed to a more general approach of self-regulation in learning: it happens when a student finds the key to be able to manage his/her own motivation for learning and for managing anxiety as a possible companion in learning. Anxiety can appear as a big problem during the exam, as well as during preparations for an exam. In psychology test anxiety represents that particular type of anxiety that happens to students as the exam becomes closer (Mengali, 2004). It is usually manifested through the following symptoms: insomnia, nervousness, irritability, difficulties with concentration, memory blanks, obsessive thoughts about the exam and even psychosomatic symptoms. Actually, test anxiety is a particular type of social anxiety that appears in all the situations in which a person feels evaluated and exposed to judgements of other people. A person that suffers from the test anxiety feels that, during the exam, he/she is not evaluated only for the preparations, but also that his/her intelligence and personal capacities are evaluated. Very anxious persons, due to nervousness, are not capable to focus to learning. In the worse cases a student can spend hours over books without learning anything. When such a situation happens, the student should use one of the strategies to manage anxiety during preparations for exam, like, for example, observe his/her own thoughts; elaborate a programme for learning; learn with others, etc.

A student with a positive attitude towards studying has a good chance to succeed in exams. It means that he/she has a wish to learn, tends to attribute meaning to everything he/she learns or does, learns by focusing on the studying topics, on the goals the he/she has to achieve and to techniques that need to be employed in order to study efficiently. Simply said, such a student puts effort because he/she understands the motivation for good learning.

Having in mind the importance of the presented evidence, we thought it would be interesting to make a research in order to explore motivation in the university context. The aim of this research is to provide data on motivation and learning strategies, as well as on possible influence of anxiety on learning process. 


\section{Method}

The present study aims to analyse motivation and learning strategies of students from $1^{\text {st }}$ through $4^{\text {th }}$ year in the university courses in Italian language. For this purpose we used a questionnaire of studying self-evaluation proposed by Cornoldi and De Beni (1993). The questionnaire provides points spread in 21 fields of studying composed of 163 statements related to personal studying habits.

\section{Participants}

93 students, 84 female and 9 male, took part in the research, varying in age from 19 to 26 . They were students in the university courses in Italian language from 1st through 4th year of Juraj Dobrila University of Pula. The university courses taken in the research were: Italian language and literature, Italian and Croatian language and literature, Italian language and literature and History, Italian and Latin language and literature, Teaching in junior classes of elementary school, and Preschool teaching.

\section{Instruments}

In this research we used a part of a questionnaire of self-evaluation by Cornoldi, De Beni and the Group MT (1993). A shorter version of the used questionnaire consists of 50 statements related to 7 fields of learning: motivation and learning success, organisation of the work, usage of tools, active elaboration of the studying material, studying flexibility, active style during lecture and anxiety. Since the original was created for the elementary and high school students, we slightly modified some statements. The questionnaire was created and administered in Italian language.

The motivation and the learning success scale consist of 8 statements considering motivation and students' intention to succeed. This field explores motivation and the wish to increase the interest of a student for university activities. A typical example of this scale's statement is the following: "I study to obtain the top marks."

The organisation of work scale consists of 6 statements that reflect organisational habits of students. A typical example of this scale's statement is the following: "When I have to prepare for a demanding oral exam, I tend to postpone as much as possible the moment of learning."

The usage of tools scale consists of 7 statements that describe how and how much students use tools while studying, such as: "I prefer to study without being interrupted to consult encyclopaedia or dictionaries."

The active material elaboration scale consists of 8 statements that reflect the way in which students elaborate the studying material. An example is: "While listening to a lecture, I link what I hear with other topics that I study."

The studying flexibility scale consists of 7 statements that describe students' habits in various situations of studying. This field refers to students' awareness of the 
complexity of learning to study and to adapt their resources and capacities to the specific demands of the tasks. A typical example is the following statement: "I decide on how to study depending on the task."

The active style during lecture scale consists of 4 statements that represent students' attitudes during lectures, such as: "While the teacher explains I notice immediately if there is something that is not quite clear to me."

The anxiety scale consists of 10 statements that represent thoughts, feelings and behaviour in various situations during lectures or exams that can be accompanied with anxiety. A typical example: "I often worry that I could fail at an oral exam."

\section{Procedure}

Students were given the questionnaire with the explanation that it serves for a research at the Juraj Dobrila University of Pula. Students were asked to fill in the questionnaire of 50 statements with a three-level answering scale: very, moderately and little.

\section{Results and discussion}

Students' answers were transformed to numerical values 1, 2 and 3. In Table 1 we can see arithmetic means and standard deviations of all the fields of learning taken into consideration in this study: motivation, organisation, usage of tools, elaboration, flexibility, activity and anxiety.

Table 1 Arithmetic means and standard deviations of the fields of learning

\begin{tabular}{|l|c|c|c|c|}
\hline \multicolumn{1}{|c|}{ Field of learning } & $\mathrm{N}$ & $\begin{array}{c}\text { Arithmetic } \\
\text { means }\end{array}$ & $\begin{array}{c}\text { Standard } \\
\text { deviations }\end{array}$ & Min. - Max. \\
\hline MOTIVATION & 93 & 17,34 & 2,66 & $8-24$ \\
\hline ORGANISATION & 93 & 12,05 & 1,84 & $6-18$ \\
\hline TOOLS & 93 & 14,95 & 2,20 & $7-21$ \\
\hline ELABORATION & 93 & 17,23 & 2,17 & $8-24$ \\
\hline FLEXIBILITY & 93 & 14,84 & 2,11 & $7-21$ \\
\hline ACTIVITY & 93 & 8,30 & 1,51 & $4-12$ \\
\hline ANXIETY & 93 & 18,84 & 2,76 & $10-30$ \\
\hline
\end{tabular}

Depending on the results on the motivation scale, participants were divided into 2 groups: the ones with results under the arithmetic mean value were considered as less motivated, while the ones with results above the arithmetic mean value were considered 
more motivated. The differences between the less and the more motivated group were analysed by using the t-test and are presented in the Table 2 .

Table 2 Differences in various fields of learning depending on the motivational level

\begin{tabular}{|c|c|c|c|c|c|}
\hline & MOTIVATION & $\mathrm{N}$ & $\begin{array}{l}\text { Arithmetic } \\
\text { means }\end{array}$ & t-test & $\mathrm{P}$ \\
\hline ORGANISATION & $\begin{array}{l}\text { less motivated } \\
\text { more motivated }\end{array}$ & $\begin{array}{l}50 \\
43\end{array}$ & $\begin{array}{l}11,42(1,74) \\
12,79(1,70)\end{array}$ & 3,83 & .001 \\
\hline TOOLS & $\begin{array}{l}\text { less motivated } \\
\text { more motivated }\end{array}$ & $\begin{array}{l}50 \\
43\end{array}$ & $\begin{array}{l}14,66(2,18) \\
15,28(2,20)\end{array}$ & 1,36 & n.s. \\
\hline ELABORATION & $\begin{array}{l}\text { less motivated } \\
\text { more motivated }\end{array}$ & $\begin{array}{l}50 \\
43\end{array}$ & $\begin{array}{l}16,74(1,89) \\
17,79(2,35)\end{array}$ & 2,38 & .019 \\
\hline FLEXIBILITY & $\begin{array}{l}\text { less motivated } \\
\text { more motivated }\end{array}$ & $\begin{array}{l}50 \\
43\end{array}$ & $\begin{array}{l}14,76(2,06) \\
14,93(2,20)\end{array}$ & 0,39 & n.s. \\
\hline ACTIVITY & $\begin{array}{l}\text { less motivated } \\
\text { more motivated }\end{array}$ & $\begin{array}{l}50 \\
43\end{array}$ & $\begin{array}{l}7,96(1,38) \\
8,70(1,57)\end{array}$ & 2,41 & .018 \\
\hline ANXIETY & $\begin{array}{l}\text { less motivated } \\
\text { more motivated }\end{array}$ & $\begin{array}{l}50 \\
43\end{array}$ & $\begin{array}{l}19,24(2,81) \\
18,37(2,65)\end{array}$ & 1,52 & n.s. \\
\hline
\end{tabular}

An interesting picture emerges from the first analyses. It shows that the more motivated students organise their work better than the less motivated students. A motivated student has more wish to study and especially to start preparing on time for an exam. Another significant difference that can be seen refers to active elaboration of the studying material. The more motivated students are more active in material elaboration, and therefore more capable in memorising and using of various strategies, compared to the less motivated ones. Furthermore, more motivated students are also more active during lectures than the less motivated students. If students are interested in the topic of the lecture, they follow easier the explanations and are keener to ask questions.

The next step of analyses refers to the differences in the levels of anxiety. Students were divided into 2 groups (more and less anxious) depending on the results obtained on the anxiety scale, same as in the motivation scale. Differences in various fields of learning between the more and the less anxious students were analysed with the t-test and are presented in the Table 3 . Statistically significant differences were found in motivation, organisation, elaboration and flexibility between students of different levels of anxiety. All the found differences are in favour of the more anxious students. Actually, the more anxious students appear to be more motivated for studying, they organise themselves better, they elaborate better studying materials and are more flexible in studying compared to the less anxious students. 
Table 3 Differences in motivation and learning strategies depending on the anxiety level

\begin{tabular}{|l|l|c|c|c|c|}
\hline & \multicolumn{1}{|c|}{ ANXIETY } & $\mathrm{N}$ & Arithmetic means & $\mathrm{t}$-test & $\mathrm{P}$ \\
\hline MOTIVATION & less anxious & 49 & $14,94(2,06)$ & $\mathbf{3 , 7 5}$ & $\mathbf{. 0 0 1}$ \\
& more anxious & 44 & $16,43(1,73)$ & & \\
\hline ORGANISATION & less anxious & 49 & $11,12(1,88)$ & $\mathbf{3 , 0 3}$ & $\mathbf{. 0 0 3}$ \\
& more anxious & 44 & $12,22(1,61)$ & & \\
\hline TOOLS & less anxious & 49 & $13,41(2,37)$ & 1,83 & n.s. \\
& more anxious & 44 & $14,29(2,29)$ & & \\
\hline ELABORATION & less anxious & 49 & $15,49(2,11)$ & $\mathbf{3 , 3 0}$ & $\mathbf{. 0 0 1}$ \\
& more anxious & 44 & $16,87(1,95)$ & & \\
\hline FLEXIBILITY & less anxious & 49 & $13,39(2,11)$ & $\mathbf{3 , 4 7}$ & $\mathbf{. 0 0 1}$ \\
& more anxious & 44 & $14,91(2,11)$ & & \\
\hline ACTIVITY & less anxious & 49 & $6,51(1,46)$ & 1,42 & n.s. \\
& more anxious & 44 & $6,93(1,40)$ & & \\
\hline
\end{tabular}

It is important to underline that the levels of anxiety found in this research are not very high, considering that even in the group of the more anxious students it is about medium high levels. Therefore, a little dose of anxiety helps student to be more motivated and to be persuaded into studying. It is important to keep anxiety always at a lower level, so that it does not make an obstacle into learning, because a higher level of anxiety reduces efficacy and the quality of learning.

Table 4 Correlations among motivation, organisation, tools, elaboration, flexibility, activity and anxiety

\begin{tabular}{|l|c|c|c|c|c|c|}
\hline & ORGANIS. & TOOLS & ELABOR. & FLEXIB. & ACTIVITY & ANX. \\
\hline MOT. & $\mathbf{0 , 4 1 * *}$ & $\mathbf{0 , 3 3} * *$ & $\mathbf{0 , 4 3} * *$ & 0,18 & $\mathbf{0 , 4 2} * *$ & 0,14 \\
\hline ORGANIS. & - & 0,19 & $\mathbf{0 , 2 3} *$ & 0,19 & $\mathbf{0 , 2 6} *$ & 0,18 \\
\hline TOOLS & & - & $\mathbf{0 , 3 9} * *$ & $\mathbf{0 , 2 8} * *$ & $\mathbf{0 , 3 2} * *$ & 0,11 \\
\hline ELABOR. & & & - & $\mathbf{0 , 3 0 * *}$ & $\mathbf{0 , 3 4 * *}$ & 0,10 \\
\hline FLEXIB. & & & & - & 0,12 & 0,09 \\
\hline ACTIVITY & & & & & - & 0,17 \\
\hline ANX. & & & & & & - \\
\hline
\end{tabular}

$*-\mathrm{p}<.01 ; * *-\mathrm{p}<.001$

Legend: Mot. - Motivation; Organis. - Organisation, Elabor. - Elaboration, Flexib. - Flexibility, Anx. - Anxiety 
In the Table 4 correlations among motivation, organisation, tools, elaboration, flexibility, activity and anxiety are shown. Looking at the correlations in the Table 4, it is possible to notice significant connections among motivations and organisation, use of tools, elaboration and activity during lecture. It means that a more motivated student is at the same time more prone to organise better his/her work, use various tools (e.g. dictionaries and atlases), elaborate more in depth the studying material and, additionally, he/she is more active during lectures. Having in mind that correlation does not tell anything about the direction, but only about the connection between variables, it is also possible to confirm the opposite - i. e. that better organisation, activity and use of didactic tools contribute to increased motivation for studying.

If we look at organisation, its correlations with elaboration and activity show that students capable to organise their work better elaborate studying material and take more active part during lectures. A good usage of tools improves elaboration, flexibility and activity; and at the same time active elaboration improves studying flexibility and active involvement. Obtained correlations indicate, as it was already stated, that a motivated student is better organised, efficient and active while studying, as well as more capable in usage of various tools. Besides, particular correlation of flexibility with the usage of tools and elaboration reveals that a good usage of tools and active elaboration improves flexibility of studying. Therefore, motivation does not influence flexibility directly, but through the use of tools and elaboration it affects the flexibility of studying.

\section{Conclusions}

In the present study we wanted to determine and explore relationships among motivation, the use of learning strategies and anxiety among university students from $1^{\text {st }}$ through $4^{\text {th }}$ year of the various university courses. From the obtained data we can confirm existence of correlation between motivation and learning strategies. It is revealed that motivation influences continuously the use of various learning strategies. More motivated students organise themselves better, they are more active, and above all they elaborate materials better compared to the less motivated students. Active elaboration increases the usage of strategies allowing the student to facilitate studying and make it more interesting. A good usage of strategies improves the quality of studying and conservation of information in the way that it links contents making knowledge extensive. Additionally, it is evident that students prove a light level of anxiety. It is positive anxiety that stimulates a student to dedicate him/herself with more determination to studying activities by improving at the same time personal organisation, elaboration and flexibility.

Looking at the conative component of motivation, it can be concluded that motivation influences learning strategies and at the same time anxiety influences motivation. Therefore, motivation and anxiety act reciprocally to each other, increasing in such a way the usage of various strategies. Definitely the most adequate way to cope with the difficulties in studying and to acquire a positive attitude in approaching 
learning is to learn about the own style of thinking, about the learning strategies and how to manage anxiety.

\section{References}

Bindra, D., Stewart, J. (1969), La motivazione, Boringhieri, Torino.

Boscolo, P. (2002), Psicologia dell'apprendimento scolastico. Aspetti cognitivi e motivazionali, UTET Libreria, Torino.

Cornoldi, C., De Beni, R., Gruppo MT. (1993), Imparare a studiare. Strategie, stili cognitivi, metacognizione e atteggiamenti nello studio, Erickson, Trento.

Mariani, L. (2000), Saper apprendere: verso la definizione di un curricolo esplicito, in: http://www.learningpaths.org/Articoli/saper_apprendere.html.

Mariani, L. (2006), Dalla parte di chi impara: le strategie di apprendimento, in: http://formare.erickson.it/archivio/dicembre_06/2_MARIANI.html.

Mariani, L. (2007), La motivazione ad apprendere come competenza da costruire: la voce degli studenti, in: http://www.learningpaths.org/Articoli/motivazionebo07.htm.

Mariani, L. (2008), Gestire la complessità: l'esempio della motivazione ad apprendere, in: http://www.learningpaths.org/Articoli/complessita.htm.

Mengali, F. (2004), Ansia, in: http://www.ansia-depressione.net/AD/ansia/ansia.html.

Metodički obzori 10, vol. 5(2010)2

Izvorni znanstveni rad

UDK: 159.953:159.947.5

Primljeno: 30. 5. 2010.

\section{MOTIVACIJA I STRETEGIJE UČENJA U STUDIJSKIM GRUPAMA S NASTAVOM NA TALIJANSKOM JEZIKU}

Prof. dr. sc. Neala Ambrosi-Randić, Sveučilište Jurja Dobrile u Puli (Hrvatska) e-mail: neala.ambrosi-randic@pu.t-com.hr

Helena Ružić, prof.

\section{Sažet a k}

$\mathrm{U}$ ovom se radu istražuje odnos motivacije, uporabe strategija učenja i anksioznosti. Istraživanje je provedeno na 93 studenta; 84 ženskog i 9 muškog spola u dobi od 19 do 26 godina. Dobiveni podaci ukazuju na postojanje značajnih pozitivnih korelacija između motivacije i strategija učenja. Studenti koji su više motivirani bolje organiziraju vlastiti rad, aktivniji su tijekom predavanja i aktivnije obrađuju sadržaj učenja u odnosu na manje motivirane studente. Anksioznost utječe na motivaciju i to 
tako da su anksiozniji studenti motiviraniji od onih manje anksioznih. Podaci potvrđuju da umjerena razina anksioznosti može pozitivno utjecati na učenje, kroz poticajno djelovanje na aktivnost i učinak.

Ključne riječi: motivacija, strategije učenja, ispitna anksioznost 